\title{
A REVIEW ON HERRING, CLUPEA HARENGUS (ACTINOPTERYGII: CLUPEIFORMES: CLUPEIDAE) RECRUITMENT AND EARLY LIFE STAGE ECOLOGY IN THE WESTERN BALTIC SEA
}

\author{
Christian VON DORRIEN ${ }^{1 *}$, Cornelius HAMMER ${ }^{1}$, Christopher ZIMMERMANN ${ }^{1}$, Daniel \\ STEPPUTTIS ${ }^{1}$, Ingo W. STUERMER ${ }^{2}$, Paul KOTTERBA ${ }^{1}$ and Patrick POLTE ${ }^{1}$ \\ ${ }^{1}$ Thünen-Institute of Baltic Sea Fisheries, Rostock, Germany \\ ${ }^{2}$ Georg-August-University of Goettingen, Department of Morphology, \\ Systematic and Biology of Evolution, Goettingen, Germany
}

\begin{abstract}
von Dorrien C., Hammer C., Zimmermann C., Stepputtis D., Stuermer I.W., Kotterba P., Polte P. 2013. A review on herring, Clupea harengus (Actinopterygii: Clupeiformes: Clupeidae) recruitment and early life stage ecology in the western Baltic Sea. Acta Ichthyol. Piscat. 43 (3): 169-182.
\end{abstract}

\begin{abstract}
Herring, Clupea harengus L., is an important commercial fish species in the Baltic Sea region since medieval times. The western Baltic spring spawning herring (WBSS) is one of three major Baltic Sea herring stocks, supporting a significant over-regional fishery in the western Baltic Sea as well as in the Kattegat and Skagerrak area. One major component spawns in the vicinity of the German island of Rügen and the associated major spawning ground, the Greifswalder Bodden (GWB), a shallow, semi-enclosed sub-system of estuarine character. Research of herring biology and ecology has an extensive history in the area probably due to the long fishery tradition and the importance of this particular herring stock for the local Baltic coast economy. In this review most of the scientific findings about WBSS in its spawning areas, mainly the GWB, is summarized. This study is based on critical review of over 120 publications and scientific sources from the past 100 years containing relevant information on possible consequences of multiple environmental and anthropogenic induced stressors of herring recruitment and productivity. Besides current peer reviewed literature a significant amount of grey literature was included, consisting primarily of papers and reports written in German language and representing the only historical data sources and published documentation of regional western Baltic herring ecology.
\end{abstract}

Keywords: Clupea harengus, western Baltic spring spawning herring, WBSS, western Baltic autumn spawning herring, recruitment, early life history, Greifswalder Bodden

\section{INTRODUCTION}

Herring, Clupea harengus L., is an important commercial fish species in the Baltic Sea region since medieval times (Jagow 1915, Meyer-Waarden 1943). In the Baltic Sea, three larger and some smaller herring stocks can be distinguished. Among the larger herring stocks occurring in the Baltic are the ones in the Bothnian Sea, in the central Baltic and in the western Baltic Sea (Fig. 1).

Western Baltic herring stocks are classified as spring or autumn spawners according to their particular spawning mode (Biester unpublished**, Klinkhardt and Reschke unpublished ${ }^{* * *}$ ). Autumn spawning herring were the dominant commercial fishery stock during the first half of the 19th century (Poulsen 1936, Anwand 1962) and supporting a large fishery until the sixties of the last century (Rechlin 1991). However, this stock has significantly decreased since the 1970s (Rechlin 2000).
The western Baltic spring spawning herring (WBSS) is the third largest of the three major Baltic Sea herring stocks with a spawning stock biomass of approximately $88000 \mathrm{t}$ in 2012 (Anonymous 2013). The WBSS supports a significant over-regional fishery, in 2012 about $21000 \mathrm{t}$ were caught in the western Baltic, while another $17000 \mathrm{t}$ were caught on the WBSS feeding grounds in the Skagerrak and Kattegat (ICES Division IIIa) (Anonymous 2013). The different life-history stages of this herring stock most probably represent key components of the Western Baltic food web. As it is known for other major herring stocks, WBSS is composed of multiple components differentiated by time and area of spawning (Ruzzante et al. 2006, Clausen et al. 2007, Clausen et al. unpublished****). One major component spawns in the vicinity of the German island of Rügen and the associated major spawning ground, the Greifswalder Bodden (GWB),

\footnotetext{
* Correspondence: Dr. Christian von Dorrien, Thünen-Institut für Ostseefischerei, Alter Hafen Süd 2, D-18069 Rostock, Germany, phone: +49-381-8116106, fax: +49-381-8116199, e-mail: christian.dorrien@ti.bund.de.

${ }^{* *}$ Biester E. 1979. Der Frühjahrshering Rügens — seine Rolle in der Fischerei der Ostsee und in den Übergangsgebieten zur Nordsee. Dissertation, Universität Rostock, Germany. ${ }^{* * * *}$ Klinkhardt M., Reschke B. 1980. Bestandszusammensetzung und Bestandsverbreitung des Herings südlich und westlich Rügens. Diplomarbeit, Universität Rostock, Germany. ${ }^{* * * * *}$ Clausen L.A.W, Ulrich-Rescan C., van Deurs M., Skagen D. 2007. Improved advice for the mixed herring stocks in the Skagerrak and Kattegat. EU Rolling Programme; Fish/2004/03. Final report
} 
a shallow, semi-enclosed sub-system of estuarine character. However, evidently additional spawning grounds do exist (e.g., in Kiel Fjord and Kiel Channel) but their contribution to WBSS recruitment is currently unknown.

Research of herring biology and ecology has an extensive history in the western Baltic area probably due to the long fishery tradition and the importance of this particular herring stock for the local Baltic coast economy. In this review, we try to summarize most of the scientific findings about the western Baltic herring stocks. The review is based on 120 publications and scientific information from the past 90 years, spanning the period between the first publication in 1919 until the year 2009. The publications contain relevant data on possible consequences of multiple environmental and anthropogenic induced stressors of herring recruitment and productivity. Besides current peer reviewed literature a significant amount of "grey literature" was included, consisting primarily of papers and reports written in German language and representing the only historical data sources and published documentation of regional western Baltic herring ecology.

An overview of the historic time line of publications included is given in Table 1. An essential amount of relevant publications on herring ecology in the Greifswalder Bodden (GWB) area originated in the 1970s and 1980s. In 1977, Biester et al. (1978) started investigating herring larvae during the spawning season in the GWB area on a sampling grid including 20 stations. This biological time series is continued to the present by the Thünen Institute of Baltic Sea Fisheries in the Rügen Herring Larvae Survey (RHLS) (Oeberst et al 2009b). Additionally, during 1984-1987 GWB spawning grounds were exemplary investigated by scientific diving (SCUBA) surveys to evaluate the spatial and temporal utilization of benthic

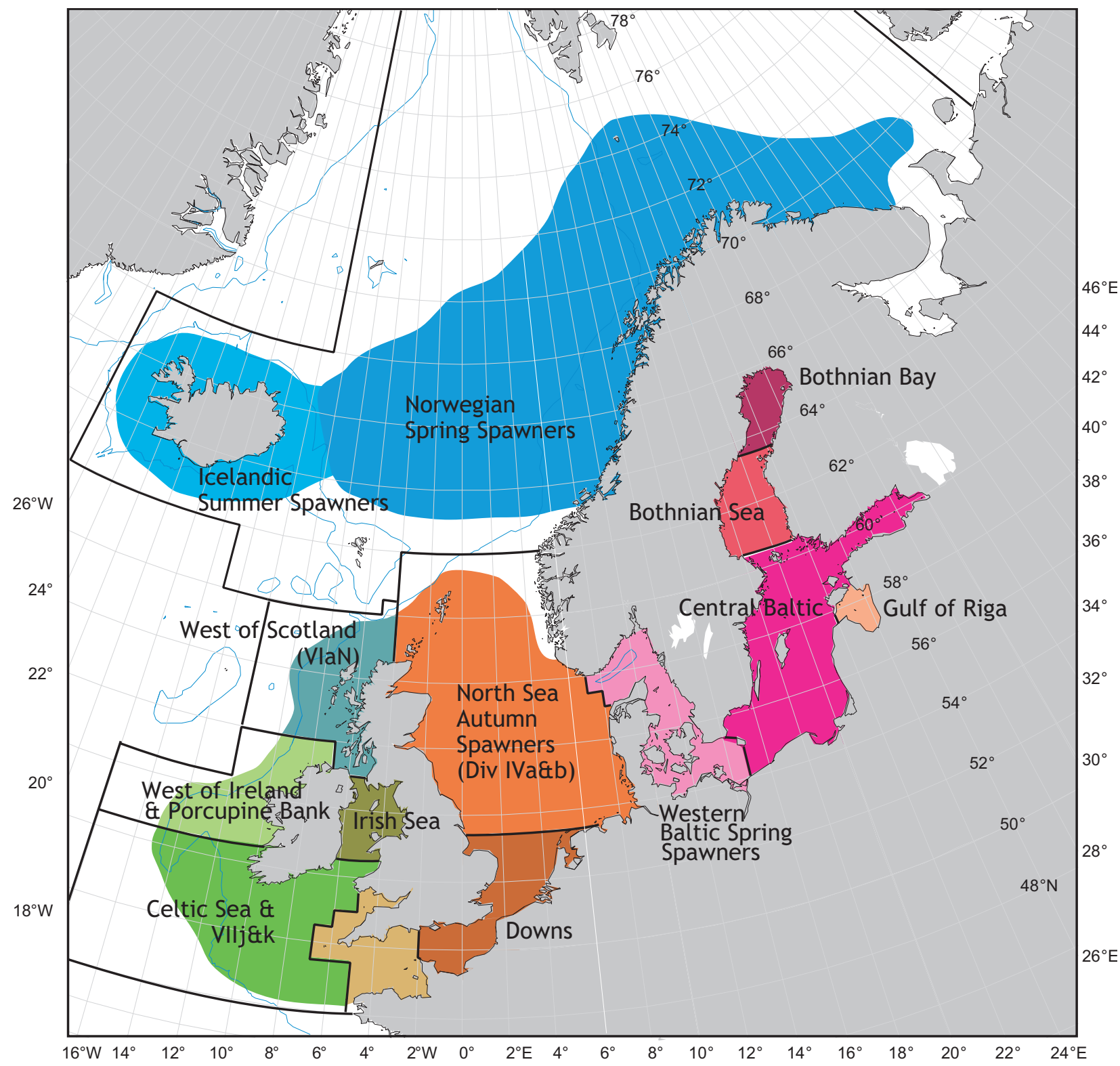

Fig. 1. The major stocks of herring, Clupea harengus L., distinguished in the Northeast Atlantic; names given on the map indicate the names of the different herring stocks 
Table 1 Historic larval investigations. Poulsen (1936) compared

Number of reviewed publications per decade dealing with recruitment and early life stage ecology of herring,

Clupea harengus L., published within 1910-2009

\begin{tabular}{lc}
\hline Decade & Number of publications \\
\hline $1910-1919$ & 1 \\
$1920-1929$ & 2 \\
$1930-1939$ & 2 \\
$1940-1949$ & 2 \\
$1950-1959$ & 4 \\
$1960-1969$ & 10 \\
$1970-1979$ & 22 \\
$1980-1989$ & 39 \\
$1990-1999$ & 16 \\
$2000-2009$ & 23 \\
\hline$\sum: 1910-2009$ & 121 \\
\hline
\end{tabular}

substrates for spawning as well as the temporal course of the spawning season (Scabell unpublished*).

The first part of the review presents published knowledge about the western Baltic autumn spawning herring. The main focus of this review lies on the western Baltic spring spawning herring (WBSS), that can be separated from central Baltic stocks by genetic differentiation (Jørgensen et al. 2005).

\section{THE WESTERN BALTIC AUTUMN SPAWNING HERRING STOCKS}

Spawning. Poulsen (1936) described two main spawning areas for the autumn spawning herring, one at the southern part of the Sound and in the coastal waters east of the islands of Møn and Falster, and the other in the Belts west of the islands of Zealand (Sjælland) and Lolland. According to Poulsen (1936), the autumn spawning herring in the Danish straits spawn on gravel or stone in rather shallow water (ca. 5-15 m) especially on the open coast or on offshore grounds.

Weber (1971) identified the most important spawning sites for autumn spawners in the western Baltic Sea off the eastern coasts of the islands of Langeland and Fehmarn. These are places laying at steeper slopes with high salinity and exposed to currents. Thus, the spawning sites differ considerably from the shallow, semi-enclosed areas (estuaries, lagoons) that are used by western Baltic spring spawning herring. The observed high concentrations of herring larvae in the Kiel Bight in autumn were explained by Weber (1971) with a so-called 'larvalpump', being a side effect of the exchange of water masses between the Danish straits and the Baltic proper. Concentrations of ripe autumn spawners were found in the deeper areas of the Mecklenburg Bight, respectively at the slopes leading to these deeper areas, below $20 \mathrm{~m}$ water depth (Berner et al. 1973). Autumn spawning herring where found to carry more eggs than spring spawning herring (Kändler and Dutt 1958). the number of herring larvae that were caught on surveys with a ring-trawl in October, with the quantity of adult herring caught during the entire spawning season that lasted from August to November. The author concludes from the results that the experimental fishing for the larvae gave a true picture of the actual number of hatched larvae.

Kändler (1952) analysed the investigations on autumn spawning herring larvae, mostly done during autumn, and combined these results with his own surveys. He concluded that the studies on the abundance of larvae of autumn spawning herring, carried out in the western and southern Baltic Sea during autumn do not provide a correct view about the strength of a single year class (Kändler 1952). Kändler (1952) reported a statement made by Dr. A.C. Jensen at the annual ICES meeting 1948, that no correlation between the number of autumn spawning herring larvae, collected during the international investigations in autumn from 1927-1938, and herring landings in the subsequent years exist; as a consequence ICES at that meeting decided to stop these surveys.

Fishery on western Baltic autumn spawners. Autumn spawning herring were the dominant commercial fishery stock during the first half of the 19th century (Poulsen 1936, Anwand 1962). However, this stock and related spawning activity is considered to have significantly decreased since the 1970s (Rechlin 2000). Poulsen (1936) reported about the quite important fishery that took place especially in September-October in the Belts, Øresund and the western Baltic, that was based on the autumn spawning herring stocks. According to Altnöder (1932), the fishery for autumn herring off the coast of Darß and Zingst was negligible, while there was an important fishery off Rügen, whereas these catches could also include spring spawning herring. At the coast of Fehmarn there was an intensive fishery for autumn spawning herring, although the catches showed a considerably variation between the years 1927-1931 (Altnöder 1932).

Berner et al. (1973) reported that the proportion of autumn spawning herring in catches from the Mecklenburg Bight in the years 1965-1970 were at $56.6 \%$ in 1965 , with the highest value in 1967 (90.0\%) and the lowest value with $26.9 \%$ in 1970 . Based on market sampling from 1965-1974 and a virtual population analysis, Weber (1978) demonstrated that the strength of autumn spawning herring cohorts decreased continuously since 1964. In the same time, fishing mortality of this stock decreased, too, probably because fishing effort on the spawning sites has decreased (Weber 1978).

Biester (unpublished**) compiled existent information and described the long-term trends of both herring stocks in the western Baltic (Table 2).

Potential reasons for the actual low densities of western Baltic autumn spawners. Poulsen (1936) assumed from his investigations over eight years (1927-1934) that the intensity of the spawning is rather small in autumns when the temperature of the water is comparatively high. According to Rechlin (1991), since the late 1960s spring

\footnotetext{
* Scabell J. 1988. Der Rügensche Frühjahrshering — das Laichgeschehen. Dissertation, Universität Rostock, Germany

${ }^{* *}$ See footnote on page 169 .
} 
spawning herring dominated the entire Baltic Sea, whereas the catches of autumn spawning herring decreased distinctly between 1966 and 1969, their proportion in catches remained on a very low level since then.

In the western Baltic, Rechlin and Borrmann (1980) showed that a high fishing mortality caused by an intensified fishery could be the reason for the decrease of the autumn spawning herring stock. However, Berner et al. (1973) assumed that the decrease of autumn spawning herring was caused by an increased frequency of oxygen depletion situations in the deeper areas of the western Mecklenburg Bight since 1966, an essential area for the spawning of this stock. They reported a decreasing water quality in the years before 1970, due to a high input of organic material, that since 1966 regularly led to low oxygen content values in the deeper water layers in summer/autumn, that were unsuitable for spawning concentrations of autumn spawning herring as well as for cod, Gadus morhua L.

Aneer (1985) put forward another hypothesis that the spawning time of Baltic herring is not genetically fixed but determined by feeding conditions during the adult phase. The author assumed, that "the present absence of autumn spawners is the result if improved feeding conditions during the last decades as a result of the eutrophication of the Baltic Sea" (Aneer 1985). Also Rechlin (1991) assumed that Baltic herring spawns either in spring or autumn, depending on local and/or temporal environmental factors.

THE WESTERN BALTIC SPRING SPAWNING HERRING RECRUITMENT AND EARLY LIFE STAGE ECOLOGY

Migration patterns. Western Baltic spring-spawning herring (WBSS) perform seasonal migrations between feeding grounds in the Skagerrak and Kattegat and their spawning sites in the western Baltic Sea (Aro 1989). The component of WBSS entering the Greifswalder Bodden (GWB) area for spawning is characterized as Rügen spring spawning herring and is genetically distinct from other components of Western Baltic herring (Jørgensen et al. 2005). Spawning adults immigrate into the GWB area from January to April when water temperatures are highly variable. The first groups arriving on the spawning grounds are older and larger in average body size compared to those later in the spawning season (Biester et al. 1978). The majority of immigrating herring enters the GWB via the eastward inlet, whereas only single specimens enter via the western narrow passage of the Strelasund (Biester et al. 1978). Tagging experiments including 17000 adult herring specimens, conducted by Biester and co-authors showed that during the initial 2 days after the catching-tagging-releasing the amount of re-captured individuals was highest. However relatively few tagged herring were re-captured in the particular area after a week or more. The authors concluded that spawners are temporary visitors on the spawning ground, leaving the area within a few days after completed spawning (Biester et al. 1978).

Fecundity. WBSS mature at approximately 2 years of age at an average total length of about $18 \mathrm{~cm}$ (Anwand 1962). The amount of eggs per ripe herring varies between approximately 20000 to 120000 eggs. The actual number of eggs is subjected to geographical and seasonal impacts (Hempel 1971). The number of eggs found in herring from the GWB area varies according to size of individuals between 11000 and 80000 (Anwand 1962). Fecundity is positively related to body size as larger females produce more and larger eggs compared to smaller individuals (Puttler unpublished*). In the Baltic Sea larger herring with a higher egg to body mass ratio $(20 \%-23 \%)$ show a significantly higher fecundity compared to small, first time spawners (egg to body mass ratio 12\%-13\%) (Kändler and Dutt 1958). Simultaneously, a higher fecundity means higher physiological stress for larger herring. Puttler (unpublished*) describes a highly significant correlation among egg diameter and body size of females. Females spawn therefore not only more but also larger eggs. The fat content of the female's tissue however does not affect egg size.

Spawning. The early life history of Rügen spring spawners takes place in estuarine inshore waters of brackish character.

Long-term trends of the western Baltic autumn spawning and spring spawning herring,

Table 2 Clupea harengus L., according to Biester (unpublished ${ }^{* *}$ )

\begin{tabular}{lll}
\hline Year & Western Baltic autumn spawners & Western Baltic spring spawners \\
\hline $1924-1927$ & Dominance in the central Baltic & Weak catches \\
1928 & End of dominance in the central Baltic & Increasing occurrence \\
1937 & Strong year class & \\
1948 & Strong year class & \\
1954 & & End of good period \\
1957 & & Minimum catches \\
1960 & & Stock starts to increase \\
1965 & & Catches start to increase \\
since 1979 & Almost impossible to catch any & Clear dominance \\
\hline
\end{tabular}

\footnotetext{
${ }^{*}$ Puttler G. 1972. Die Abhängigkeit der Eigröße von der Konstitution der Mutter beim Hering (Clupea harengus L.) der westlichen Ostsee. Dissertation, Christian-AlbrechtsUniversität Kiel, Germany.

${ }^{* *}$ See footnote on page 169 .
} 
This is considered to have major physiological consequences on early herring life stages (Klinkhardt 1986a). Interestingly, WBSS spawns almost exclusively on aquatic vegetation whereas other North Atlantic herring stocks, like the western Baltic autumn spawning herring (Poulsen 1936), use gravel beds for spawning. Experiments using artificial spawning substrate showed that females are in direct contact with the substrate during spawning (Aneer et al. 1983, Scabell and Jönssen 1984).

The selection of retention areas (sensu Iles and Sinclair 1982) and vegetated shore zones for spawning means that the amount of suitable spawning areas is limited and reproduction success of WBSS is highly vulnerable to human-induced habitat alteration and shore line modification. Scabell and Jönssen (1984) mention the effects of increased nutrient runoff, building of waterways and shoreline modification on the abundance and distribution of aquatic vegetation.

Mild winters with none or limited ice coverage in the Greifswalder Bodden (GWB) lead to an early beginning of spawning activity (Scabell unpublished ${ }^{*}$ ). First mass occurrences of herring larvae are regularly observed during March and water temperatures of western and Central Baltic Sea are the key factors determining the starting point and further progression of spawning (Brielmann unpublished $\left.{ }^{* *}\right)$. At the beginning of the spawning time more adult females than males are found in the area but with proceeding spawning season the ratio between sexes becomes balanced. Biester et al. (1978) observed a higher ratio of male herring towards the end of the spawning period. In case there are similar size groups of fish from different years classes, older individuals arrive about 14 days earlier at the spawning area than the one-year younger individuals. Fuchs (unpublished ${ }^{* * *}$ ) defined two types of the yearly spawning events: The most common type is "main spawning" framed by minor spawning events at the margins of spawning period. The second type lacks this central spawning peak. Noteworthy is the fact that individuals that firstly arrive on spawning grounds contain more and larger eggs than smaller herring that follow. Klinkhardt (1986b) provided evidence that during 1982 and 1983 the major egg deposition occurred at the beginning of the spawning season and showed the lowest mortality. The egg diameter decreases with proceeding spawning season from $1.4 \mathrm{~mm}$ in April to $1.3 \mathrm{~mm}$ in June (Scabell unpublished*). Smaller eggs spawned later in the season at higher temperatures, contain less yolk and hatched larvae are of worse condition (Puttler unpublished $^{* * * *}$ ). Egg mortality as well as mortality of larvae at hatching increases with proceeding spawning season (Rajasilta et al. 2006).

Egg development. In the Greifswalder Bodden (GWB), the oxygen content of the water body is distributed relatively homogeneously due to permanent wind driven mixing and the particular bathymetry and shallow character of this spawning ground (Schnese 1973, Kell 1989). Only at high temperatures during low wind summer conditions mixing can be temporarily reduced. Under regular conditions, however, herring eggs and larvae in the GWB develop within a well-oxygenated water body with rare occasions below $80 \%$. In in vitro experiments the required oxygen concentration for suitable herring eggs aeration and resulting embryonic development was measured. The amount of oxygen needed per individual herring egg during the first days after fertilization was found to range at 20-30 ng $\mathrm{O}_{2}$ per hour and rises exponentially with proceeding development (Kiørboe and Møhlenberg 1987). With increasing size of the embryo internal transport routes extend and oxygen consumption increases. Overall, only about $25 \%$ of the consumed oxygen is invested into somatic growth processes (Kiørboe and Møhlenberg 1987).

The relation between the body length of hatched larvae and the oxygen content during incubation can be summarized as follows: At oxygen level of $50 \%$ the body length of hatchlings decreases. The time to hatching increases with the decreasing $\mathrm{O}_{2}$ content. The control groups incubated under $100 \%$ oxygen saturation always hatched 15-17 days after fertilization, whereas larvae incubated at lower $\mathrm{O}_{2}$ partial pressures hatched approximately 4 days later (Braum 1973).

Investigations by divers showed that herring eggs are often attached to apical portions of aquatic plants such as Furcellaria, where they might stick to each other induced by wave action (Klinkhardt and Biester 1984). Multiplelayer-spawning was repeatedly observed for spring spawning herring (Klinkhardt and Biester 1985). Scabell (unpublished*) found multiple-layer spawning at 5.4\% of all analyzed field samples. Bonding of herring eggs in clumps or multiple layers might lead to oxygen depression in lower layers and therefore to increased egg mortality (Klinkhardt and Biester 1984). The repeated spawning on already egg-covered substrate leads to "covering" of early spawned eggs that contain higher developmental stages affecting their further development or even survival. The covered eggs, oxygen depressed and additionally suffering from poisoning by accumulating excrements initially slow down in their development and eventually die (Klinkhardt and Biester 1985).

Hempel and Schubert (1969) observed that the mortality of herring eggs as well as the amount of embryonic deformation increased from upper to lower egg layers within a particular spawn aggregation. Hempel (unpublished ${ }^{* * * * *}$ ) showed that an oxygen decrease translates into lower numbers of the hatched larvae. As a consequence of mass hatching, the oxygen consumption increases resulting in a lowered partial pressure of $\mathrm{O}_{2}$ intensifying the increased hatching- increased respiration cascade. Blaxter (1956) experimentally showed that the more eggs are packed together; the lower is the percentage of successful hatching.

Light winds and low wave action can contribute to aeration of spawn, support spawning success, and induce hatching (Scabell unpublished ${ }^{*}$ ). Moderate wind force can induce spontaneously high abundances of newly hatched larvae. Strong winds however, might harm shallow water spawning beds (Hourston and Rosenthal 1976). At wind forces of 4 Beaufort (Bft) eggs in a depth up to $2.5 \mathrm{~m}$ can

\footnotetext{
* See footnote on page 171 .

* Brielmann N. 1981. Quantitative Untersuchungen an den Larven des Rügenschen Frühjahrsherings (Clupea harengus L.) im Greifswalder Bodden und in angrenzenden Gewässern. Diplomarbeit, Universität Rostock, Germany.

${ }_{* * * *}^{*}$ Fuchs F. 1985. Einschätzung der Laichaktivität des Rügenschen Frühjahrshering (Clupea harengus) im nordöstlichen Greifswalder Bodden. Diplomarbeit, Universität Rostock, Germany. 
be impacted by turbulences. Wind forces of $8 \mathrm{Bft}$ and more lead to wave action and hydrodynamic forcing down to a depth of $6 \mathrm{~m}$ and induce heavy losses of spawning substrate during storm events.

Concerning the egg mortality, Klinkhardt (1986b) hints on the fact that during two observed years, the egg mortality oscillated closely around $33 \%$, regardless variability of environmental conditions. Based on this observation, Klinkhardt (1986a) concluded that the primary factor determining the hatching success is the initial amount of spawned eggs rather than the post-spawning effect of the environmental factors.

The majority of field studies on herring biology featured a concurrent water temperature recording (Nybelin 1929) and the temperature readings are available today in high spatial- and temporal resolution (Feistel et al. 2008). The water temperatures of the western Baltic area are subject to tremendous seasonal temperature fluctuations ranging from below $0^{\circ} \mathrm{C}$ in winter to peaks exceeding $20^{\circ} \mathrm{C}$ in summer. In the GWB area, Schoknecht (1973) compared water temperature data recorded on the surface and on the bottom (depths: 6-8 $\mathrm{m}$ ) and concluded that because of the wind-induced turbulence the shallow basin generally lacked thermoclines and the vertical temperature range was only $0.3-1{ }^{\circ} \mathrm{C}$.

For WBSS the spawning temperature threshold is $3-4^{\circ} \mathrm{C}$ (Klinkhardt 1996) which was confirmed in the GWB where the first significant amounts of spawn were found at this temperature (Klinkhardt and Biester 1985).

The temperature range of the main spawning event is related to particular requirements of an individual stock. In the Northern Baltic Sea herring spawns at spring temperatures of $5-13^{\circ} \mathrm{C}$. For autumn spawners, however, a temperature range of $9-17^{\circ} \mathrm{C}$ has been reported (Ojaveer 1981). Blaxter (1956) assumes that the preferred spawning temperature for spring spawning herring is $5-8^{\circ} \mathrm{C}$ and for autumn spawners $9-14^{\circ} \mathrm{C}$. Successful egg development under extreme temperatures were described by Riedel (1957) in relation to aquaculture feasibility studies. According to this author, herring eggs covered with ice at $0-1{ }^{\circ} \mathrm{C}$ can survive transportation from Scotland to South Africa, where they hatch after a 50 days incubation, becoming 7-9 $\mathrm{mm}$ long larvae. At $14-19^{\circ} \mathrm{C}$ the incubation takes 6-8 days yielding 5-6 $\mathrm{mm}$ long hatchlings. Embryonic heart rates of incubated eggs have been measured in vitro and showed that the initial cardiac activity of WBSS embryos occurred 1 day earlier when incubation temperature was increased from $8^{\circ} \mathrm{C}$ to $10^{\circ} \mathrm{C}$ at a salinity of PSS 15 (Rosenthal 1967). The author also showed that most 8 days old embryos dye if the eggs are transferred from $10^{\circ} \mathrm{C}$ to $14^{\circ} \mathrm{C}$ temperate water. Herring eggs experimentally exposed to temperature amplitude fluctuations of $11^{\circ} \mathrm{C}$ in 12 and $24 \mathrm{~h}$ intervals, respectively, showed a highly negative correlation of the temperature amplitudes with the larval length (Kiemer unpublished ${ }^{*}$ ). An established view of the influence of constant temperatures on the various stages of development before and after hatching bases on the unit "degree-days", i.e. the product of temperature and development time as days. (Klinkhardt 1996). According to Klinkhardt (1996) it can be concluded that an increase in temperature from $4^{\circ} \mathrm{C}$ to $6^{\circ} \mathrm{C}$ can result in an approximately 1 week reduction of egg development time. At higher temperatures (i.e., $12-14^{\circ} \mathrm{C}$ ) a similar difference only leads to a 2.5-day reduction in egg development.

For spring and autumn spawners of the British waters the minimum temperature threshold of successful egg development has been defined by Blaxter (1956) as $1.3^{\circ} \mathrm{C}$. With this he calculated a theoretical temperature threshold of "biological zero temperature" below which the development of near-hatchlings will halt. According to Blaxter (1960), the lowest lethal temperature below which $50 \%$ of individuals die within $24 \mathrm{~h}$-ranges from -0.8 through $-1.8^{\circ} \mathrm{C}$. In the $\mathrm{GWB}$, the hatching takes place at higher temperatures. Temperature has a significant effect on the development of embryonic myoblasts (Johnston 1993). The upper temperature limit of hatching in summer time cannot be clearly defined. Blaxter and Hempel (1961) stated that the hatching rates at $14^{\circ} \mathrm{C}$ were lower than those at $5-11^{\circ} \mathrm{C}$. However, the authors did not test for temperatures $>14^{\circ} \mathrm{C}$. Their study is also characterized by relatively weak fertilization- and hatching rates leading to the assumption that requirements for optimal development were not achieved in the experimental setup.

Very little published sources concerning the predation on herring eggs in the Baltic Sea area are available. Dense populations of certain predatory bird species coinciding with the herring spawning sites have been observed in the Baltic Sea several times. During the herring spring spawning seasons between 1980 and 1982, Leipe and Sellin (1983) observed numerous aggregations of greater scaup, Aythya marila (up to 34000 individuals at a particular site) and long-tailed duck, Clangula hyemalis (up to 45000 individuals) in the area of the GWB. Leipe (1985) also described the accumulation of long-tailed ducks on GWB spawning grounds. The author revealed an $18 \%$ average diet contribution of herring eggs based on 115 analysed duck stomachs. Sellin (1990) postulated that the choice for the GWB as wintering site for greater scaup and the long-tailed duck was prompted by the high productivity of the benthic community in that shallow area. Žydelis and Esler (2005) described aggregation of Steller's eider, Polysticta stelleri, on herring spawning grounds alongside the Lithuanian coast and demonstrated the importance of the temporarily available spawn for the feeding ecology of these birds. Stempniewicz (1995) discovered the presence of herring spawn in $25 \%$ of all analysed stomach samples of long-tailed duck taken in the Gulf of Gdańsk.

The impact of fish on the herring recruitment by predating on herring spawn has not been sufficiently examined in the Baltic Sea. Rajasilta et al. (1993) analysed the impact of invertebrate and fish predators on the spawning of herring in the Archipelago Sea, Finland. Their results indicate a negligible role of littoral invertebrates but a remarkable relevancy of abundant perch, Perca fluviatilis L. On the other hand, Torniainen and Lehtiniemi

\footnotetext{
* Kiemer M. 1990. Auswirkungen von Kalterbrütung und Temperaturundulation auf die Embyonalentwicklung des Herings, Clupea harengus. Diplomarbeit, Universität Hamburg, Germany.
} 
(2008) demonstrated in an experimental study that the three littoral mysids (Neomysis integer, Praunus flexuosus, and $P$. inermis) prey on herring eggs and yolk-sac larvae, if available. Scabell (unpublished*) suspected threespined stickleback Gasterosteus aculeatus L.; flounder Platichthys flesus (L.); eelpout Zoarces viviparus (L.); perch Perca fluviatilis; and roach Rutilus rutilus (L.) to feed on the spawn in the GWB area but further investigation on these interactions is still lacking.

Hatching and larval development. The daily growth rate of larvae after hatching is considered similar along the different herring races (Norwegian, Downs, Baltic herring) and the daily increment is on the average $0.16 \mathrm{~mm}$. Western Baltic herring larvae grow faster at higher temperatures and show an average daily growth rate of $0.2 \mathrm{~mm}$ per day (Weber 1971) and Northern Baltic herring grows as much as $0.18-0.52 \mathrm{~mm}$ per day (Hakala et al. 2003). A temperature increase by $1^{\circ} \mathrm{C}$ causes an increase of daily growth by an average of $0.043 \mathrm{~mm}$, which is an acceleration of growth by 8-24 percentage points, depending on initial water temperatures. With increasing temperatures the time that larvae can survive relying only on their yolk reservoir decreases. Body length of larvae at the end of the yolk sac stage and the survival times are positively correlated with the size of eggs (Blaxter and Hempel 1963). Since WBSS belong to a stock with relatively small eggs, the time between fertilization and first feeding is limited to about 25 days at moderate temperatures of $9-12^{\circ} \mathrm{C}$. The point of no return (meaning a temporal threshold after which even suitable food supply will not prevent larval death) is considered to be reached after about two weeks. The larval survival after hatching without food intake is for instance limited to 15 instead of 20 days if temperature increases from 5 to $8^{\circ} \mathrm{C}$ (Blaxter and Hempel 1963). Investigations of the pre-hatching yolk consumption by Puttler (unpublished ${ }^{* *}$ ) showed that only half of the yolk is converted into larval body substance whereas the second half is used by the larval metabolism. At hatching, half of the yolk is used for larval/embryonic growth and one third is already metabolized, leaving newly hatched larvae at relatively high temperatures of $9-12^{\circ} \mathrm{C}$ with only $20 \%$ of the original yolk reservoir. Busch (unpublished ${ }^{* * *}$ ) describes the following consequences of early vs. late seasonal hatching for herring larvae in the GWB area: larvae recruiting from earlier spawning events have a larger yolk reservoir. This is a significant advantage since they are provided with more energy reserves at lower temperatures. Thus they grow towards a seasonally increasing plankton food supply and are able to improve their predation skills before energy becomes limited. Although they grow into a seasonally advanced plankton community that might soon be subject to decreasing abundance, larvae hatched from later spawning do not necessarily have a disadvantage. The relatively small yolk reservoir in combination with high yolk consumption at higher temperatures implies that larvae experience a faster transition towards active feeding. They, however, start feeding at times with higher prey abundance and might compensate for smaller size at hatching by more effective yolk utilization becoming effective zooplankton predators. During herring early life history, food supply (Casini et al. 2006) and water temperatures are probably limiting factors of the eventual year class strength (Nash and Dickey-Collas 2005). Temperatures (surface and bottom) are also described to be the major factor structuring strength of Pacific herring stocks (Williams and Quinn 2000). Western Baltic herring larvae differ from larvae of North Sea herring by faster growth and development (Schnakenbeck 1929, Arrhenius and Hansson 1996, Oeberst et al 2009a). Morphological differences to other herring populations are not distinguishable in the yolk sac stage and no distinct morphological separation can be made between Baltic and North Sea herring.

In the central Baltic Sea a correlation between the abundance of copepod Pseudocalanus elongatus and average herring weight can be observed since the 1980s (Möllmann et al. 2003). Although fertilization rates are fairly high even under unfavourable environmental conditions (Ojaveer 1981), the vulnerability of the embryo increases with increasing egg development. At time of hatching temperature, oxygen content and other environmental factors gain impact on larval survival.

In the literature, growth rates of herring larvae are predominantly investigated for the range of $1-12^{\circ} \mathrm{C}$. In the GWB, in the coastal Baltic and North Sea temperatures can reach about $20.5^{\circ} \mathrm{C}$. Therefore, Oeberst et al. (2009a) developed a model to quantify and statistically verify the weekly growth of larvae in the GWB area during spring time in relation to temperature and other variables of the water body for the time period between 1992 and 2006 . Using a multiple linear regression approach they showed that besides water temperatures other variables, such as salinity, density, time of the year, etc. had no significant effect on larval growth. Oeberst et al. (2009a) concluded that more than $50 \%$ of growth variability is explained by temperature variation. Within the range up to $10^{\circ} \mathrm{C}$ the data of Oeberst et al. (2009a) correspond with data of other authors. For the range above $10^{\circ} \mathrm{C}$, however, data show a higher growth than in other studies on the subject. Therefore Oeberst et al. (2009a) concluded that Rügen herring is tolerant to relatively high temperatures and values up to $17.5^{\circ} \mathrm{C}$ do not have any negative effect on average growth rates.

Herring larvae respond more sensitively to oxygen depletion than juvenile and adult fish (Braum 1973). One reason that early life stages of herring are more sensitive than older fish is their limited ability to actively avoid unfavourable conditions (Breitburg 2002). Experiments conducted by de Silva and Tytler (1973) resulted in a definition of the particular dose per age group that induces $50 \%$ mortality $\left(\mathrm{LD}_{50}\right)$. The $\mathrm{LD}_{50}$ for 7 -week old herring larvae was reached at $2.9 \mathrm{ng} \mathrm{O} \mathrm{O}_{2} \cdot \mathrm{L}^{-1}$ and for 2 weeks old larvae $3.1 \mathrm{ng} \mathrm{O}_{2} \cdot \mathrm{L}^{-1}$ respectively. Yolk sac larvae, however, showed the highest tolerance with an $\mathrm{LD}_{50}$ of $1.9 \mathrm{ng} \mathrm{O}_{2} \cdot \mathrm{L}^{-1}$. Oxygen consumption increases with temperature and body size of larvae (Almatar 1984,

\footnotetext{
* See footnote on page 171.

** See footnote on page 172 .

${ }^{* * *}$ Busch A. 1993. Nahrungsökologische Untersuchungen an den Larven des Rügenschen Frühjahrsherings (Clupea harengus L.) im Greifswalder Bodden in den Jahren 1990 bis 1992. Dissertation, Universität Rostock, Germany.
} 
Kiørboe and Møhlenberg 1987), however, oxygen uptake rates are reported to change if larvae experience short periods without food ingestion (Yin and Batty 1995). Later herring larvae start schooling at an approximate age of 6 weeks after hatching and at a length between 18-20 mm are able to swim 3-6 m within 5 min (Rosenthal 1968). After metamorphosis they are able to actively avoid oxygen-depleted zones. Chapman and Mckenzie (2009) showed that herring respond to increasing oxygen depletion by increased swimming velocity. This reaction is induced within minutes and can be observed at oxygen contents limited to $50 \%-60 \%$. Although local fluctuations of dissolved oxygen can hardly fatally harm highly mobile larvae, as long as they are able to avoid oxygen depleted zones, they can induce behavioural changes like increased swimming velocities.

Cnidarians and planktivorous fish are regarded to be the most important herring larvae predators. Examinations of jelly fish abundances and gut contents at the Pacific East coast (Canada and Alaska) revealed the predation rate of hydromedusae includes up to $12.5 \%$ per day of the standing stock of early fish life stages (Purcell et al. 1987, Purcell 1989, Purcell and Grover 1990).

Field investigations and mesocosm experiments in the North Atlantic verified the relevance of scyphomedusae and ctenophores as larval fish predators, although their volume-specific clearance rate of $4 \%-7 \%$ ranged significantly lower than those of planktivorous fish (Cowan and Houde 1993). The moon jellyfish, Aurelia aurita, is known to be an effective predator on fish larvae and is therefore subject of several studies on herring larvae predation. Lynam et al. (2005) showed a significant negative correlation between jellyfish abundances and the recruitment success of herring in the North Sea. Bailey and Batty (1983) experimentally found an average ingestion rate of 7 herring larvae per hour for even very small sized A. aurita (12-14 $\mathrm{mm}$ diameter) demonstrating the capacity of this species as important larvae predator. A. aurita is known to occur in the Baltic Sea in sufficient quantities as to play an important role in the top down regulation of WBSS (Möller 1980). Additionally Möller (1984) demonstrated a negative effect of high $A$. aurita medusae abundances on the survival of herring larvae in the Kiel Bight. However, in the GWB, high densities of $A$. aurita normally occur only after the main spawning season in early summer (authors' own unpublished observation).

Little is known about the impact of other invertebrate predators on the larvae of herring. The hyperiid amphipod, Hyperoche medusarum, feeds intensively on newly hatched larvae of Pacific herring (von Westernhagen 1976, von Westernhagen et al. 1979b). In the Baltic Sea, littoral mysids have been observed to feed on early yolk-sac larvae of herring (Torniainen and Lehtiniemi 2008).

Herring larvae provide an important food source for several planktivorous fish species, at least for the juvenile stages of certain taxa. Piscine herring larvae predation has been described for sprat, Sprattus sprattus (L.) (see Fuiman and Gamble 1988); sandeels (Fuiman and
Gamble 1988, Rankine and Morrison 1989); juvenile cod, Gadus morhua L. (see Fuiman and Batty 1994); juvenile salmonids (Manzer 1969); gobies (Utne-Palm 2000); and for smelts Osmerus eperlanus (L.) (see Horbowa 2001).

Cannibalism in terms of juvenile herring feeding on larvae of their own species is generally accepted. Enclosure experiments demonstrated that herring larvae are regularly selected as prey by juvenile herring (Hourston et al. 1981, Gamble and Fuiman 1987, Fuiman and Gamble 1988, Fuiman 1989, Fuiman 1991, Fuiman and Batty 1994).

\section{EFFECTS OF PARTICULAR ENVIRONMENTAL VARIABLES ON EARLY LIFE STAGE ECOLOGY} Nutrients and eutrophication. The Baltic Sea is particularly exposed to eutrophication due to intensive agricultural land use and limited water exchange with the North Sea and Atlantic. Because of high nutrient input, intense algal blooms can occur not only during spring time but also during the summer month. These algal blooms include pelagic and benthic algae that can accumulate and lead to hypoxia in deeper zones by biological decomposition. An increased abundance of benthic algae cannot only harm spawning beds by physical over growth but might also negatively affect fish eggs by released toxic substances, as experiments carried out by Aneer (1987) demonstrated for herring eggs from the northern Baltic Sea.

Western Baltic spring spawning herring (WBSS) requires aquatic vegetation for spawning. On unvegetated soft-substrates almost no spawning activity could be observed (Klinkhardt and Biester 1984, Kääriä et al. 1988, Rajasilta et al. 1989). Reduction of aquatic plants in the spawning areas therefore potentially threatens reproduction. Macrophytes react very sensitively to high nutrient input. As a consequence of increased growth of phytoplankton, the water column becomes turbid, leading to light limitation and finally to a reduction of suitable macrophytes habitats. A strong indication for these processes is the shift of macrophyt distribution from deeper areas towards shallower areas in coastal waters as recent investigations in German coastal waters of the Baltic have proved (Anonymous 2008).

During the last few decades, filamentous green algae (i.e., Ulva spp.; Cladophora spp.) became increasingly abundant in the Baltic Sea (Aneer 1985, Munkes 2005). As a consequence, other algal species, such as the brown algae Fucus vesiculosus, a highly frequented spawning substrate (Pilz unpublished*), were displaced. Lindner (1978) reports the replacement of original plant communities by increasing Cladophora stocks in impaired waters of inshore Baltic ecosystems. The increased algal growth is most probably a consequence of nutrient loads that doubled between 1965 and 1976 and then further increased (Aneer 1985). As an obvious consequence of eutrophication of coastal waters, also in the German Baltic high concentrations of filamentous algae, like Pylaiella littoralis, Ceramium sp. Polysiphonia sp, were found to settle among and upon sea grass plants. (Anonymous 2008). 
Kääriä et al. (1988) brought up evidence that a decrease of herring landings at the Southwest Finland coasts were directly related to increasing nutrient load.

Turbidity. Any local or large-scale construction projects that are carried out at or near herring spawning sites might influence spawning success due to increased turbidity. Examples for such projects are power plants planned at the coast of the Greifswalder Bodden, construction of gas pipelines crossing the same area or the construction of a fixed link between Germany and Denmark across the Fehmarnbelt. The introduction or re-suspension of sediment material bears risks to fish production besides the input of organic material that might result in increased nutrient load. On Finish coasts Kääriä et al. (1988) and Rajasilta et al. (2006) demonstrated that a substantially increased concentration of suspended matter changed the substrate towards muddy bottoms, thus reducing the potential spawning grounds of herring. Both an increased input and a high re-suspension of suspended matter are negative for the reproductive success of herring. Increased turbidity is known to limit the photic zone and thus decrease vertical distribution and community structure of aquatic vegetation. Therefore changes in turbidity can have drastic effects on fish that obligatory requires vegetation as a spawning substrate. As a more direct effect on suspended matter on herring reproduction Rosenthal (1971) points out how serious deposition of fine material on herring eggs can harm embryonic development by impaired gas exchange, resulting in significantly increased mortality and deformation rate of embryos (Braum 1973). Rosenthal (1971) further reports that suspended muddy sediment can block the esophagus of larvae and affect their food intake. However, Kiørboe et al. (1981) did not find any correlation between experimentally induced amounts of suspended sediment and hatching success of herring. The authors emphasize, however, that the experimental setup included $100 \%$ oxygen saturation which might not resemble natural conditions where sediment load in the water column is often accompanied by limited contents of dissolved oxygen. Herring larvae are visual hunters. A significant turbidity might therefore negatively affect their predation success and thus their nutritional status. Johnston and Wildish (1982) experimentally showed that the hunting success of herring larvae is significantly reduced with increasing turbidity by suspended sediments. Generally, according to Fox et al. (1999) the maximum water depth suitable for visual predation by herring larvae might be reduced for $50 \%$ by turbidity.

Pollutants. Small amounts of particular dissolved heavy metals, such as copper $(\mathrm{Cu})$ and zinc $(\mathrm{Zn})$, are essential trace elements important for the structure and function of organic systems and physiological processes. These particular elements however can be of major toxicity to aquatic biota if introduced to the system in higher concentrations. Other heavy metals, such as cadmium $(\mathrm{Cd})$ and mercury (Hg) do not have any biological value but are highly toxic even at low concentrations (Senocak 1995). Obviously biotic response to heavy metal toxicity is highly variable according to elements involved and concentrations. Deformations of fish embryos are documented for Cd concentrations of $80 \mu \mathrm{g} \cdot \mathrm{L}^{-1}$, whereas for $\mathrm{Hg}$ concentrations of $10 \mu \mathrm{g} \cdot \mathrm{L}^{-1}$ already causes damage (von Westernhagen 1988). The negative impact of $\mathrm{Cu}$ on survival of herring eggs, however, is about 800 times higher than that of $\mathrm{Cd}$ (von Westernhagen et al. 1979a). The threat of dissolved toxins to herring predominantly concerns the development of eggs and larvae. Potential impacts range from changes in behaviour and limited activity to different degrees of deformation and death of fish eggs or larvae. In the literature often lethal and sub-lethal toxic effects are differentiated. Von Westernhagen (1988) emphasizes, that the facts are more properly described by "acutely and not acutely lethal" and heavy metals, such as $\mathrm{Cd}$, damaged the membranes of fertilized eggs.

McKim (1977) summarizes in his review the effects of different levels of pollutant concentration and tries to define the maximum acceptable toxic concentration (MATC) of major toxins in terms of their impact on the development of fish. Pohl et al. (2008) document in their report on the situation of heavy metals in the Baltic Sea 2007 a slight increase of diversity of heavy metal particles $(\mathrm{Cd}, \mathrm{Cu}$, and $\mathrm{Zn}$ ) but simultaneously they show a decrease of concentrations. Overall, the authors state that the heavy metal contamination of the Baltic Sea is not subjected to high fluctuations and does not reach any harmful level.

Heavy metals in particular might have lethal consequences for embryonic growth and result in drastic egg mortalities. According to Rosenthal and Sperling (1974) hatching rates are significantly reduced at a $\mathrm{Cd}$ content of $0.1 \mathrm{ppm}$ although it remains relatively high until a content of $5 \mathrm{ppm}$. At a rate of $0.05 \mathrm{ppm} \mathrm{Zn}$ the amount of larvae with deformed gills and jaws significantly increases compared to unexposed control individuals. At a $\mathrm{Zn}$ contamination of $6.0 \mathrm{ppm}$ the deformation rate reaches $100 \%$ (Somasundaram et al. 1984). A combination of multiple heavy metals might increase harmful effects (von Westernhagen 1988). The uptake of heavy metals can be influenced by the salinity. The impact of $\mathrm{Cd}$ is higher the lower the salinity of the water is (Dethlefsen et al. unpublished*).

Herring easily takes up large amounts of pollutants such as mercury from the surrounding water and with the diet. Either the accumulation takes place directly through the skin surface or through the gills (Senocak 1995). Therefore adult herring is continuously exposed to toxins, even during the spawning period where herring does not or very little feed.

Even small amounts of heavy metals, hydrocarbons (oil), or pesticides can affect the number of eggs within the herring ovaries and reduce those for up to 80 percentage points (von Westernhagen 1988). Fertilization can be significantly impacted in contaminated water. Kinne and Rosenthal (1967), investigating potential effects of dumping of chemical waste, noted that the amount of fertilized eggs decreased from $82 \%$ to $46 \%$ in the presence of sulphur compounds, such as $\mathrm{FeSO}_{4}$ and $\mathrm{H}_{2} \mathrm{SO}_{4}$, in a solution of $1: 16000$. Toxic sulphate compounds although present

\footnotetext{
* Dethlefsen V., von Westernhagen H., Rosenthal H. 1975. Accumulation of cadmium by embryos of herring, flounder and garpike under different salinity regimes. ICES CM 1975/E:9, Fisheries Improvement Committee.
} 
in concentrations too low to induce any mortality effects might nevertheless cause behavioural changes like a lack of predatory instincts eventually affecting survival rates (Kinne and Rosenthal 1967). Generally, larvae hatched under contaminated conditions are considered less mobile and show reduced activity (von Westernhagen 1988).

Chlorinated allopathic hydrocarbons do not have any measurable impact on fertilization according to Rosenthal and Alderdice (1976). Decreases of $\mathrm{pH}$ i.e., by sulphates can reduce water intake of eggs (von Westernhagen 1988). Kelley (1946) documented for Pacific herring a lack of embryonic development and hatching of deformed larvae at slightly acidic conditions below $\mathrm{pH} 7$. A slightly alkaline $\mathrm{pH}$, however, at about $\mathrm{pH} 10$ does not result in a delayed egg development.

Generally, all major impacts of pollutants predominantly affect hatching success. The hydrocarbons contained in petroleum products in higher concentrations $\left(>5 \mathrm{~mL} \cdot \mathrm{L}^{-1}\right)$ significantly reduce the hatch rate causing $100 \%$ mortality (Lindén 1978). According to von Westernhagen (1988) aromatic hydrocarbons can block the phosphatization of ADP, and thus lead to deformations of early embryonic stages. Besides genetic damaging an increased heart rate and irregular muscle contractions of the embryo can indicate toxic effects (Rosenthal and Alderdice 1976).

\section{CONCLUSIONS}

After centuries of exploitation of herring stocks and more than 100 years of intense research, information on herring ecology in the Baltic Sea area is quite plenty. The international scientific community, however, may have a limited access to many publications because historic information was frequently published in the national languages of the many countries bordering the Baltic Sea. In reviewing the historic "grey" literature written in German and synthesizing this information with more current research, a major aim of this literature review was to aggregate and retrieve the knowledge on the ecology of commercially relevant herring stocks such as the western Baltic spring spawning herring (WBSS). The results reveal a great deal of information and data existing on herring ecology in general and on WBSS in particular. More than $80 \%$ of the articles reviewed were published during the past 40 years, with a maximum of publications during the 1980s. Many of these papers were originally published in German and thus a considerable part of important and interesting results remained internationally inaccessible.

Migration routes of WBSS from feeding grounds in the North Sea to the spawning grounds in the western Baltic area are comparatively well documented. Less is known about the fate of adult herring after they accomplished mating and spawning. Considerable research was carried out about the process of spawning and the development of eggs. Accordingly it is assumed that the initial amount of spawned eggs and the process of egg development on a certain area is an important phase for the recruitment success before additional post-hatching effects and environmental forces on larval development become dominant. Temperature related growth rates of herring larvae are well investigated, as are consumption rates and food requirements. Information and especially quantitative data on predators and predation rates on spawn and herring larvae is rarely available.

Despite the strong research history of herring ecology, there are still important knowledge gaps to be addressed. For example, the reasons for the low recruitment rates of WBSS observed during recent years are still not fully understood. Therefore, further research is needed to isolate the particular drivers of herring recruitment in the western Baltic Sea, in the context of natural ecosystem dynamics and human induced environmental alteration along the shores of the Baltic Sea.

\section{ACKNOWLEDGEMENTS}

We do thank three anonymous reviewers for their very valuable comments on the first version of the manuscript.

This review was partly financed and conducted as part of the Fehmarn Belt Science Provision Project.

\section{REFERENCES}

Almatar S.M. 1984. Effects of acute changes in temperature and salinity on the oxygen uptake of larvae of herring (Clupea harengus) and plaice (Pleuronectes platessa). Marine Biology 80 (2): 117-124. DOI: 10.1007/BF02180178

Altnöder K. 1932. Bericht über die III. und IV. Untersuchungsfahrt zur Feststellung des Vorkommes der Herbstheringslarven in den Laichperioden 1930 und 1931. Berichte der Deutschen Wissenschaftlichen Kommission für Meeresforschung 6 (2): 26-42.

Aneer G. 1985. Some speculations about the Baltic herring (Clupea harengus membras) in connection with the eutrophication of the Baltic Sea. Canadian Journal of Fisheries and Aquatic Sciences 42 (Suppl. 1): s83-s90. DOI: 10.1139/f85-264

Aneer G. 1987. High natural mortality of Baltic herring (Clupea harengus) eggs caused by algal exudates? Marine Biology 94 (2): 163-167. DOI: 10.1007/BF00392928

Aneer G., Florell G., Kautsky U., Nellbring S., Sjöstedt L. 1983. In-situ observations of Baltic herring (Clupea harengus membras) spawning behaviour in the Askö-Landsort area, northern Baltic proper. Marine Biology 74 (2): 105-110. DOI: 10.1007/BF00413912

Anonymous 2008. Bericht über die aktuelle Bewertung der Gewässergüte und Bewirtschaftungsziele für den Greifswalder Bodden. Landesamt für Umwelt, Naturschutz und Geologie Mecklenburg-Vorpommern (LUNG), Güstrow, Germany.

Anonymous 2013. Herring in Division IIIa and Subdivision 22-24 (western Baltic spring spawners). Advice May 2013. ICES 6.4.8 Ecoregion Stock, Advice for 2014.

Anwand K. 1962. Die Fruchtbarkeit der Frühjahrs- und Herbstheringe aus den Gewässern um Rügen. Zeitschrift für Fischerei 11 (5-6): 463-473.

Aro E. 1989. A review of fish migration patterns in the Baltic. Rapports et procès-verbaux des réunions. Conseil Permanent International pour 1'Exploration de la Mer 190: 72-96. 
Arrhenius F., Hansson S. 1996. Growth and seasonal changes in energy content of young Baltic Sea herring (Clupea harengus L.). ICES Journal of Marine Science 53 (5): 792-801. DOI: 10.1006/jmsc.1996.0100

Bailey K.M., Batty R.S. 1983. A laboratory study of predation by Aurelia aurita on larval herring (Clupea harengus): Experimental observations compared with model predictions. Marine Biology 72 (3): 295-301. DOI: 10.1007/BF00396835

Berner M., Rechlin O., Rohde K.H., Schulz S. 1973. Umweltbedingte Fluktuationen der Dorsch- und Heringsfischerei in der Mecklenburger Bucht. FischereiForschung Rostock 11 (1): 7-18.

Biester E., Jönsson N., Brielmann N. 1978. Fischereibiologische Untersuchungen am Rügenschen Frühjahrshering 1975-1977. Wissenschaftliche Zeitschrift der Universität Rostock 27 (4): 417-437.

Blaxter J. 1956. Herring rearing II-The effect of temperature and other factors on development. Marine Research Scotland 5: 2-19.

Blaxter J.H.S. 1960. The effect of extremes of temperature on herring larvae. Journal of the Marine Biological Association of the United Kingdom 39 (3): 605-608. DOI: 10.1017/S0025315400013576

Blaxter J., Hempel G. 1961. Biologische Beobachtungen bei der Aufzucht von Heringsbrut. Helgoländer wissenschaftliche Meeresuntersuchungen 7 (5): 260-283. DOI: 10.1007/BF01880280

Blaxter J., Hempel G. 1963. The Influence of egg size on herring larvae (Clupea harengus L.). ICES Journal of Marine Science 28 (2): 211-240. DOI: 10.1093/icesjms/28.2.211

Braum E. 1973. Einflüsse chronischen exogenen Sauerstoffmangels auf die Embryogenese des Herings (Clupea harengus). Netherlands Journal of Sea Research 7: 363-375. DOI: 10.1016/0077-7579(73)90058-6

Breitburg D. 2002. Effects of hypoxia, and the balance between hypoxia and enrichment, on coastal fishes and fisheries. Estuaries 25 (4b): 767-781. DOI: 10.1007/BF02804904

Casini M., Cardinale M., Hjelm J. 2006. Inter-annual variation in herring, Clupea harengus, and sprat, Sprattus sprattus, condition in the central Baltic Sea: what gives the tune? Oikos 112 (3): 638-650. DOI: 10.1111/j.0030-1299.2006.13860.x

Chapman L., Mckenzie D.J. 2009. Chapter 2. Behavioural responses and ecological consequences. Pp. 25-77. In: Richards J.G., Farrell A.P., Brauner C.J. (eds.) Hypoxia. Fish Physiology series Vol. 27. DOI: 10.1016/S1546-5098(08)00002-2

Clausen L.A.W, Bekkevold D., Hatfield E.M.C., Mosegaard H. 2007. Application and validation of otolith microstructure as a stock identification method in mixed Atlantic herring (Clupea harengus) stocks in the North Sea and western Baltic. ICES Journal of Marine Science 64 (2): 377-385. DOI: $10.1093 /$ icesjms/fs1036

Cowan J.H.jr., Houde E.D. 1993. Relative predation potentials of scyphomedusae, ctenophores and planktivorous fish on ichthyoplankton in Chesapeake Bay. Marine Ecology Progress Series 95: 55-65.

de Silva C.D., Tytler P. 1973. The influence of reduced environmental oxygen on the metabolism and survival of herring and plaice larvae. Netherlands Journal of Sea Research 7: 345-362. DOI: 10.1016/0077-7579(73)90057-4

Feistel R., Nausch G., Wasmund N. (eds.) 2008. State and evolution of the Baltic Sea, 1952-2005. A detailed 50-year survey of meteorology and climate, physics, chemistry, biology, and marine environment. John Wiley and Sons, Hoboken, NJ, USA.

Fox C., Harrop R., Wimpenny A. 1999. Feeding ecology of herring (Clupea harengus) larvae in the turbid Blackwater estuary. Marine Biology 134 (2): 353-365. DOI: 10.1007/s002270050552

Fuiman L.A. 1989. Vulnerability of Atlantic herring larvae to predation by yearling herring. Marine Ecology Progress Series 51: 291-299.

Fuiman L.A. 1991. Influence of temperature on evasive responses of Atlantic herring larvae attacked by yearling herring, Clupea harengus L. Journal of Fish Biology 39 (1): 93-102. DOI: 10.1111/j.1095-8649.1991.tb04344.x

Fuiman L.A., Batty R.S. 1994. Susceptibility of Atlantic herring and plaice larvae to predation by juvenile cod and herring at two constant temperatures. Journal of Fish Biology 44 (1): 23-34. DOI: 10.1111/j.10958649.1994.tb01582.x

Fuiman L.A., Gamble J.C. 1988. Predation by Atlantic herring, sprat, and sandeels on herring larvae in large enclosures. Marine Ecology Progress Series 44: 1-6.

Gamble J.C., Fuiman L.A. 1987. Evaluation of in situ enclosures during a study of the importance of starvation to the vulnerability of herring larvae to a piscine predator. Journal of Experimental Marine Biology and Ecology 113 (2): 91-103. DOI: 10.1016/0022-0981(87)90157-2

Hakala T., Viitasalo M., Rita H., Aro E., Flinkman J., Vuorinen I. 2003. Temporal and spatial variation in the growth rates of Baltic herring (Clupea harengus membras L.) larvae during summer. Marine Biology 142 (1): 25-33. DOI: 10.1007/s00227-002-0933-3

Hempel G. 1971. Egg production and egg mortality in herring. Rapports et Proces-verbaux des Réunions. Conseil International pour l'Éxploration de la Mer 160: 8-11.

Hempel G., Schubert K. 1969. Sterblichkeitsbestimmungen an einem Eiklumpen des Nordsee-Herings (Clupea harengus L.). Berichte der Deutschen Wissenschaftlichen Kommission für Meeresforschung 20: 79-83.

Horbowa K. 2001. Fish larvae as food for age group 1 smelt Osmerus eperlanus (L.) in the Vistula Lagoon (Poland) in spring 1998 and 1999. Bulletin of the Sea Fisheries Institute 2 (153): 63-68.

Hourston A., Rosenthal H. 1976. Viable hatch from herring eggs torn loose from substrates by storms. Fisheries and Marine Service. Environment Canada. Technical Report No. 653.

Hourston A.S., Rosenthal H., Kerr S. 1981. Capacity of juvenile Pacific herring (Clupea harengus pallasi) to feed on larvae of their own species. Canadian Technical Report of Fisheries and Aquatic Sciences No. 1044.

Iles T., Sinclair M. 1982. Atlantic herring: Stock discreteness and abundance. Science, New Series 215 (4533): 627-633.

Jagow K. 1915. Die Heringsfischerei an den deutschen Ostseeküsten im Mittelalter. Archiv für Fischereigeschichte 5: 1-45. 
Jørgensen H.B.H., Hansen M.M., Bekkevold D., Ruzzante D.E., Loeschcke V. 2005. Marine landscapes and population genetic structure of herring (Clupea harengus L.) in the Baltic Sea. Molecular Ecology 14 (10): 3219-3234. DOI: 10.1111/j.1365-294X.2005.02658.x

Johnston D.D., Wildish D.J. 1982. Effect of suspended sediment on feeding by larval herring (Clupea harengus harengus L.). Bulletin of Environmental Contamination and Toxicology 29 (3): 261-267. DOI: 10.1007/BF01706226

Johnston I.A. 1993. Temperature influences muscle differentiation and the relative timing of organogenesis in herring (Clupea harengus) larvae. Marine Biology 116 (3): 363-379. DOI: 10.1007/BF00350053

Kääriä J., Eklund J., Hallikainen S., Kääriä R., Rajasilta M. 1988. Effects of coastal eutrophication on the spawning grounds of the Baltic herring in the SW Archipelago of Finland. Kieler Meeresforschung Sonderheft 6: 348-356.

Kändler R. 1952. Über das Laichen des Frühjahrsherings bei Rügen und die Häufigkeit der Brut des Herbstherings in der Beltsee und südlichen Ostsee. Kieler Meeresforschungen 8 (2): 145-163.

Kändler R., Dutt S. 1958. Fecundity of Baltic herring. Rapports et Proces-verbaux des Réunions. Conseil International pour l'Éxploration de la Mer 143: 99-108.

Kell V. 1989. Das Phytoplankton des Greifswalder Boddens. Meer und Museum 5: 25-35.

Kelley A.M. 1946. Effect of abnormal $\mathrm{CO}_{2}$ tension on development of herring eggs. Journal of the Fisheries Research Board of Canada 6e (6): 435-440. DOI: 10.1139/f42-051

Kinne O., Rosenthal H. 1967. Effects of sulfuric water pollutants on fertilization, embryonic development and larvae of the herring, Clupea harengus. Marine Biology 1 (1): 65-83. DOI: 10.1007/BF00346697

Kiørboe T., Frantsen E., Jensen C., Sørensen G. 1981. Effects of suspended sediment on development and hatching of herring (Clupea harengus) eggs. Estuarine, Coastal and Shelf Science 13 (1): 107-111. DOI: 10.1016/S03023524(81)80109-0

Kiørboe T., Møhlenberg F. 1987. Partitioning of oxygen consumption between "maintenance" and "growth" in developing herring Clupea harengus (L.) embryos. Journal of Experimental Marine Biology and Ecology 111 (2): 99-108. DOI: 10.1016/0022-0981(87)90048-7

Klinkhardt M. 1986a. Gedanken zur Abhängigkeit der Laichentwicklung Rügenscher Frühjahrsheringe (Clupea harengus L.) von Umweltparametern. Fischerei-Forschung Rostock 24 (2): 22-27.

Klinkhardt M. 1986b. Ergebnisse von Untersuchungen zur Schlupf- und Dottersackphase der Larven von Rügenschen Frühjahrsheringen (Clupea harengus L.). FischereiForschung Rostock 24 (2): 28-30.

Klinkhardt M. 1996. Der Hering Clupea harengus. Die Neue BrehmBücherei 199. Westarp Wissenschaftenverlagsgesellschaft, Magdeburg, Germany.

Klinkhardt M., Biester E. 1984. Erste Ergebnisse von experimentellen Felduntersuchungen am Laich von Rügenschen Frühjahrsheringen. Fischerei-Forschung Rostock 22 (3): 76-78.
Klinkhardt M., Biester E. 1985. Untersuchungen zum Ablauf der Frühjahrslaichsaison 1982 und 1983 der Rügenheringe (Clupea harengus L.) auf einem ausgewählten Laichplatz des Greifswalder Boddens. Fischerei-Forschung 23 (4): 41-48.

Leipe T. 1985. Zur Nahrungsökologie der Eisente (Clangula hyemalis) im Greifswalder Bodden. Beiträge zur Vogelkunde 31: 121-140.

Leipe T., Sellin D. 1983. Zum Vorkommen von Bergenten (Aythya marila) und Eisenten (Clangula hyemalis) auf dem Greifswalder Bodden. Ornithologischer Rundbrief Mecklenburgs 26: 34-47.

Lindén O. 1978. Biological effect of oil on early development of the Baltic herring Clupea harengus menbras. Marine Biology 45 (3): 273-283. DOI: 10.1007/BF00390611

Lindner A. 1978. Soziologisch-ökologische Untersuchungen an der submersen Vegetation in der Boddenkette südlich des Darß und Zingst (südlich Ostsee). Limnologica 11: 229-305.

Lynam C.P., Heath M.R., Hay S.J., Brierley A.S. 2005. Evidence for impacts by jellyfish on North Sea herring recruitment. Marine Ecology Progress Series 298: 157-167. DOI: $10.3354 / \operatorname{meps} 298157$

Manzer J.I. 1969. Stomach contents of juvenile Pacific salmon in Chatham sound and adjacent waters. Journal of the Fisheries Research Board of Canada 26 (8): 2219-2223. DOI: 10.1139/f69-207

McKim J. 1977. Evaluation of tests with early life stages of fish for predicting long-term toxicity. Journal of the Fisheries Research Board of Canada 34 (8): 1148-1154. DOI: 10.1139/f77-172

Meyer-Waarden P.F. 1943. Die Zeesenfischerei auf Hering und Sprott, ihre Entwicklung und Bedeutung für die Ostseefischerei und ihre Auswirkungen auf den Blankfischbestand der Ostsee. Julius Neumann, Neudamm, Germany.

Möller H. 1980. Population dynamics of Aurelia aurita medusae in Kiel Bight, Germany (FRG). Marine Biology 60 (2-3): 123-128. DOI: 10.1007/BF00389155

Möller H. 1984. Reduction of a larval herring population by jellyfish predator. Science 224 (4649): 621-622. DOI: 10.1126/science. 224.4649 .621

Möllmann C., Kornilovs G., Fetter M., Köster F.W., Hinrichsen H.-H. 2003. The marine copepod, Pseudocalanus elongatus, as a mediator between climate variability and fisheries in the Central Baltic Sea. Fisheries Oceanography 12 (4-5): 360-368. DOI: 10.1046/j.13652419.2003.00257.x

Munkes B. 2005. Eutrophication, phase shift, the delay and the potential return in the Greifswalder Bodden. Baltic Sea. Aquatic Sciences 67 (3): 372-381. DOI: 10.1007/s00027005-0761-x

Nash R.D.M., Dickey-Collas M. 2005. The influence of life history dynamics and environment on the determination of year class strength in North Sea herring (Clupea harengus L.). Fisheries Oceanography 14 (4): 279-291. DOI: 10.1111/j.1365-2419.2005.00336.x

Nybelin O. 1929. Heringslarven im Kattegat und in der südlichen Ostsee. Svenska Hydrografisk-Biologiska Kommissionens Skrifter; Ny Serie: Biologi 1 (3): 3-15. 
Oeberst R., Dickey-Collas M., Nash R.D.M. 2009a. Mean daily growth of herring larvae in relation to temperature over a range of $5-20^{\circ} \mathrm{C}$, based on weekly repeated cruises in the Greifswalder Bodden. ICES Journal of Marine Science 66 (8): 1696-1701. DOI: 10.1093/icesjms/fsp193

Oeberst R., Klenz B., Gröhsler T., Dickey-Collas M., Nash R.D.M., Zimmermann C. 2009b. When is year-class strength determined in western Baltic herring? ICES Journal of Marine Science 66 (8): 1667-1672. DOI: 10.1093/icesjms/fsp143

Ojaveer E. 1981. Influence of temperature, salinity and reproductive mixing of Baltic herring groups on its embryonal development. Rapports et Proces-verbaux des Réunions. Conseil International pour l'Éxploration de la Mer 178: 409-415.

Pohl C., Hennings U., Leipe T. 2008. Die Schwermetallsituation in der Ostsee im Jahre 2007. Meereswissenschaftliche Berichte 72: 95-129.

Poulsen E. 1936. On a correlation between the yearly catch of herring in the Sound and the abundance of herring larvae in autumn. Rapports et Proces-verbaux des Réunions. Conseil International pour l'Éxploration de la Mer 100: 22-24.

Purcell J.E. 1989. Predation on fish larvae and eggs by the hydromedusa Aequorea victoria at a herring spawning ground in British Columbia. Canadian Journal of Fisheries and Aquatic Sciences 46 (8): 1415-1427. DOI: 10.1139/f89-181

Purcell J.E., Grover J.J. 1990. Predation and food limitation as causes of mortality in larval herring at a spawning ground in British Columbia. Marine Ecology Progress Series 59: 55-61.

Purcell J.E., Siferd T.D., Marliave J.B. 1987. Vulnerability of larval herring (Clupea harengus pallasi) to capture by the jellyfish Aequorea victoria. Marine Biology 94 (2): 157-162. DOI: 10.1007/BF00392927

Rajasilta M., Eklund J., Hänninen J., Kurkilahti M., Kääria J., Rannikko P., Soikkeli M. 1993. Spawning of herring (Clupea harengus membras L.) in the Archipelago Sea. ICES Journal of Marine Science 50 (3): 233-246. DOI: 10.1006/jmsc. 1993.1026

Rajasilta M., Eklund J., Kääriä J., Ranta-Aho K. 1989. The deposition and mortality of the eggs of the Baltic herring, Clupea harengus membras L., on different substrates in the south-west archipelago of Finland. Journal of Fish Biology 34 (3): 417-427. DOI: 10.1111/j.1095-8649.1989.tb03324.x

Rajasilta M. Eklund J., Laine P., Jönsson N., Lorenz T. 2006. Intensive monitoring of spawning populations of the Baltic herring (Clupea harengus membras L.); Final report of the study project ref. N. 96-068, 1997-1999. SEILI Archipelago Research Institute Publications No. 3.

Rankine P.W., Morrison J.A. 1989. Predation on herring larvae and eggs by sand-eels Ammodytes marinus (Rait) and Hyperoplus lanceolatus (Lesauvage). Journal of the Marine Biological Association of the United Kingdom 69 (2): 493-498. DOI: 10.1017/S0025315400029556

Rechlin O.K.W. 1991. Tendencies in the herring population development of the Baltic Sea. Internationale Revue der gesamten Hydrobiologie und Hydrographie 76 (3): 405-412. DOI: 10.1002/iroh.19910760313

Rechlin O. 2000. Fischbestände der Ostsee, ihre Entwicklung seit 1970 und Schlussfolgerungen für ihre fischereiliche
Nutzung-Teil 2: Hering. Informationen für die Fischwirtschaft aus der Fischereiforschung 47 (1): 25-30.

Rechlin O., Borrmann H. 1980. Causes of the decline in Southern Baltic herring. Rapports et Proces-verbaux des Réunions. Conseil International pour l'Éxploration de la Mer 177: 154-158.

Riedel D. 1957. Der Hering. Die neue Brehm-Bücherei. Ziemsen Verlag, Wittenberg, Germany.

Rosenthal H. 1967. Die Herztätigkeit von Heringsembryonen bei verschiedenen Temperaturen. Helgoländer wissenschaftliche Meeresuntersuchungen 16 (1-2): 112-118. DOI: $10.1007 / \mathrm{BF} 01620692$

Rosenthal H. 1968. Schwimmverhalten und Schwimmgeschwindigkeit bei den Larven des Herings Clupea harengus. Helgoländer wissenschaftliche Meeresuntersuchungen 18 (4): 453-486. DOI: $10.1007 / \mathrm{BF} 01611680$

Rosenthal H. 1971. Wirkungen von „Rotschlamm“ auf Embryonen und Larven des Herings Clupea harengus. Helgoländer wissenschaftliche Meeresuntersuchungen 22 (3-4): 366-376. DOI: 10.1007/BF01611125

Rosenthal H., Alderdice D.F. 1976. Sublethal effects of environmental stressor, natural and pollutional, on marine fish and larvae. Journal of the Fisheries Research Board of Canada 33 (9): 2047-2065. DOI: 10.1139/f76-253

Rosenthal H., Sperling K.-R. 1974. Effects of cadmium on development and survival of herring eggs. Pp. 383-396. In: Blaxter J.H.S. (ed.) The early life history of fish. Springer, Berlin Heidelberg, Germany. DOI: 10.1007/978-3-642-65852-5_32

Ruzzante D.E., Mariani S., Bekkevold D., André C., Mosegaard H., Clausen L.A.W., Dahlgren T.G., Hutchinson W.F., Hatfield E.M.C., Torstensen E., Brigham J., Simmonds E.J., Laikre L., Larsson L.C., Stet R.J.M., Ryman N., Carvalho G.R. 2006. Biocomplexity in a highly migratory pelagic marine fish, Atlantic herring. Proceedings of the Royal Society Part B Biological Sciences 273 (1593): 1459-1464. DOI: 10.1098/rspb.2005.3463

Scabell J., Jönssen N. 1984. Untersuchungen zum natürlichen Laichverhalten des Rügenschen Frühjahrshering im Greifswalder Bodden. Fischerei-Forschung Rostock 22 (3): 68-72.

Schnakenbeck W. 1929. Entwicklungsgeschichtliche und morphologische Untersuchungen am Hering. Berichte der Deutschen Wissenschaftlichen Kommission für Meeresforschung 5 (2): 5-60.

Schnese W. 1973. Untersuchungen zur Produktionsbiologie des Greifswalder Boddens (südliche Ostsee) I. die Hydrographie: Salzgehalt, Sauerstoffgehalt, Temperatur und Sestongehalt. Wissenschaftliche Zeitschrift der Universität Rostock 22 (6-7) 629-639.

Schoknecht G. 1973. Einige Untersuchungsergebnisse über die Wasserbeschaffenheit des Greifswalder Boddens. Acta hydrochimica et hydrobiologica 1 (4): 387-395. DOI: 10.1002/aheh.19730010407

Sellin D. 1990. Fischlaich als Nahrung von Vögeln. Die Vogelwelt 111 (6): 217-224.

Senocak T. 1995. Schwermetalluntersuchungen an Fischen der deutschen Ostseeküste (Kliesche, Limanda limanda; 
Flunder, Platichthys flesus; Hering Clupea harengus und Dorsch, Gadus morhua). Kieler Meeresforschung (270): 1-206.

Somasundaram B., King P.E., Shackley S.E. 1984. Some morphological effects of zinc upon the yolk-sac larvae of Clupea harengus L. Journal of Fish Biology 25 (3): 333-343. DOI: 10.1111/j.1095-8649.1984.tb04880.x

Stempniewicz L. 1995. Feeding ecology of the long-tailed duck Clangula hyemalis wintering in the Gulf of Gdansk (southern Baltic Sea). Ornis Svecica 5: 133-142.

Torniainen J., Lehtiniemi M. 2008. Potential predation pressure of littoral mysids on herring (Clupea harengus membras L.) eggs and yolk-sac larvae. Journal of Experimental Marine Biology and Ecology 367 (2): 247-252. DOI: 10.1016/j.jembe.2008.10.007

Utne-Palm A.C. 2000. Prey visibility, activity, size and catchability's (evasiveness) influence on Gobiusculus flavescens prey choice. Sarsia 85 (2): 157-165. DOI: 10.1080/00364827.2000.10414565

von Westernhagen H. 1976. Some aspects of the biology of the hyperiid amphipod Hyperoche medusarum. Helgoländer wissenschaftliche Meeresuntersuchungen 28 (1): 43-50. DOI: $10.1007 / \mathrm{BF} 01610795$

von Westernhagen H. 1988. 4. Sublethal effects of pollutants on fish eggs and larvae. Pp. 253-346. In: Hoar W.S., Randall D.J. (eds.) The physiology of developing fish eggs and larvae. Fish Physiology series Vol. 11, Part A. DOI: 10.1016/S1546-5098(08)60201-0

von Westernhagen H., Dethlefsen V., Rosenthal H. 1979a. Combined effects of cadmium, copper and lead on develop- ing herring eggs and larvae. Helgoländer wissenschaftliche Meeresuntersuchungen 32 (3): 257-278. DOI: 10.1007/BF02189585

von Westernhagen H., Rosenthal H., Kerr S., Fürstenberg G. 1979b. Factors influencing predation of Hyperoche medusarum (Hyperiida: Amphipoda) on larvae of the Pacific herring Clupea harengus pallasi. Marine Biology 51 (3): 195-201. DOI: 10.1007/BF00386798

Weber W. 1971. Die Laichplätze des Herings (Clupea harengus L.) der westlichen Ostsee. Kieler Meeresforschung 27: 194-208.

Weber W. 1978. Bestandsanalyse für den Hering der westlichen Ostsee. Informationen für die Fischwirtschaft aus der Fischereiforschung 25 (3/4): 94-95.

Williams E., Quinn T.J.II 2000. Pacific herring, Clupea pallasi, recruitment in the Bering Sea and north-east Pacific Ocean, II: relationships to environmental variables and implications for forecasting. Fisheries Oceanography 9 (4): 300-315. DOI: 10.1046/j.1365-2419.2000.00146.x

Yin M.-c., Batty R.S. 1995. Effect of temperature under unfavourable conditions on oxygen uptake of larval herring, Clupea harengus. Chinese Journal of Oceanology and Limnology 13 (3): 258-265. DOI: 10.1007/BF02850528

Žydelis R., Esler D. 2005. Response of wintering Steller's eiders to herring spawn. Waterbirds 28 (3): 344-350.

Received: 8 April 2013

Accepted: 27 August 2013

Published electronically: 30 September 2013 